\title{
Structural analysis of consequences of corruption in the environmental sector in modern society
}

\author{
Vadim Burukin ${ }^{1}$, Victor Vezlomtsev ${ }^{1}$, Svetlana Vezlomtseva $^{1}$, Alena Zvyagina ${ }^{1}$, and \\ Vyacheslav Sevalnev ${ }^{2, *}$ \\ ${ }^{1}$ Academy of the Federal penitentiary service of Russian Federation, 1 Sennaya str., Ryazan, 390000, \\ Russian Federation \\ ${ }^{2}$ Institute of Legislation and Comparative Law under the Government of the Russian Federation, \\ Cheremushkinskaya str., 34, Moscow, 117218, Russia
}

\begin{abstract}
This article shows the dialectic influence of phenomenon of corruption on the social reality of modern society. The main approaches to assessing the consequences of corruption processes are considered. Through the prism of these approaches, a structural analysis of consequences of corruption in economic, political, social and spiritual spheres of society is carried out. Based on the philosophical principle of reflection, factors of social danger of corruption are identified, main manifestations of corruption affecting the formation of the image of social reality are described. The article provides a critical analysis of the revisionist approach. Its supporters believe that corruption can be viewed as a natural phenomenon that manifests itself in the transitional periods of development of society, with a change in the norms of its functioning and the lack of consensus, as well as a kind of mediator that unites the emerging privileged and excluded strata a changing society. The main function of corruption within this approach is to preserve the unity and maintain the integrity of socio-economic system in certain conditions, after which corruption should disappear. The laws of dialectics are manifested in this area of human interactions. Therefore, we can talk about the socially constructive function of studied social phenomenon. It is shown that the ratio of constructive and destructive consequences of corruption manifestations in various social systems and at different stages of their historical development varies.
\end{abstract}

\section{Introduction}

In the modern world, corruption takes place in any society, any state. There are practically no countries that could declare its complete absence. Moreover, the specificity of its current stage is its pronounced international character (Table 1). This is determined by a number of factors, the most important of which is globalization, which determines economic transparency of national borders, free movement of capital, labor, etc., as well as

\footnotetext{
*Corresponding author: sevalnev77@gmail.com
} 
criminalization of national economies. The relevance of the corruption issue is associated with the variety of its consequences. In addition to its direct impact on economic processes, corruption has an outlet in the socio-political space. We have to figure out, what exactly is this influence.

The purpose of this analysis is a socio-philosophical understanding of consequences of corrupt practices in modern society. The purpose predetermines formulation of specific research tasks, the solution of which constitutes the content of this article:

- studying and systematization of modern theoretical and methodological approaches to understanding corruption and its consequences in the framework of foreign and domestic science;

- showing the main destructive consequences of corruption manifestations for society;

- analyzing the possible social and constructive consequences of corruption.

\section{Methods}

Corruption is a rather complex phenomenon that has not been systematically explored. It should be emphasized that, although the research tradition related to the issue of corruption has existed for a long time, it began to act as an independent object of analysis only from the mid-1950s. Among modern foreign studies on corruption, the most significant are the works of K. Friedrich and S. Huntington, written in the 70s. XX century, as well as studies of the 2000 s by S. Rose-Ackerman and L. Holmes.

As for domestic theoretical studies of the issue of corruption in recent years, it is worth noting the works of S.V. Bondarenko, A.S. Bystrova and M.V. Silvestros, S.V. Maksimov, V.I. Rimsky, V.I. Verkhovin, N.R. Pravnikova, S.V. Alekseev.

A special place in the study of the issue of corruption takes the empirical research of G.A. Satarov, M.V. Krasnov, Kh.V. Dzutsev, whose works raise the issues of perception of corruption by various social groups, as well as the structural and dynamic features of corruption.

It is noteworthy that the issue of directly corrupt relations and consequences of corruption is raised only in a few works of modern domestic researchers of corruption: A.S. Minzov, V.L. Latov, G.A. Satarov; and foreign ones - E. Lauler and L. Hipp.

The issues of social control of corruption are studied by P. Langsez, N.A. Gushchina and N.A. Rener, A.A. Kontarev, N. Chen, D. Lange.

An analysis of scientific literature allows us to conclude that the study of corruption by domestic and foreign researchers provides significant material for understanding the topical issues under consideration. In the course of the study, the methods of systemic, comparative, structural and functional analysis, dialectical and historical approaches were used. An important place in the work is occupied by the institutional approach, which makes it possible to consider corruption both as a separate, independent phenomenon and as a social institution interacting with other social systems and institutions. The greatest opportunities are given by considering this issue from the point of view of social functions and dysfunctions, set by the research of T. Parsons and R. Merton: the idea of violating the norms of compulsory behavior accepted in society.

\section{Results}

The study has shown that corruption is currently systemic in nature and affects almost all aspects of society, acting as one of the elements of social reality. The reasons for the emergence and reproduction of corrupt practices lie in the constantly developing and changing conditions of interaction between the citizens and the state. For this reason, the 
study of corruption involves, first of all, an understanding of its nature and causal relations with other phenomena. These phenomena are dialectically interconnected, and since corruption is multifaceted, we can talk about both socially destructive functions and socially constructive functions of this social phenomenon. This does not mean justifying corruption, but is a reflection of objective reality.

Table 1. Ranking of countries in the world according to the Corruption Perceptions Index in 2019.

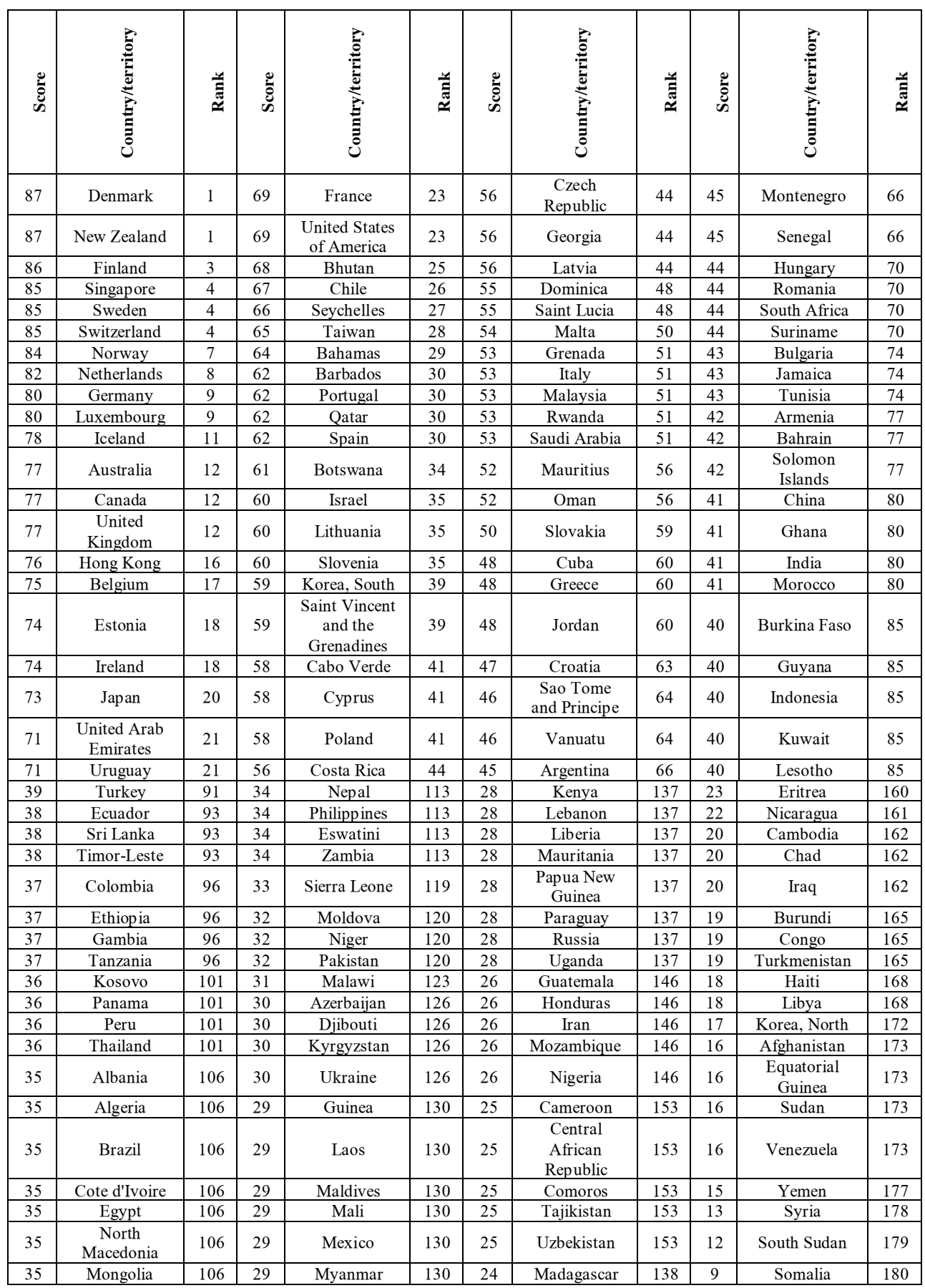




\begin{tabular}{|l|l|l|l|l|l|l|l|l|l|l|l|}
\hline 34 & El Salvador & 113 & 29 & Togo & 130 & & & & & & \\
\hline
\end{tabular}

\section{Discussion}

There are different points of view regarding the assessment of the impact of corruption on the nature of social development in the humanities. Most scholars believe that corruption has an extremely negative impact on all aspects of public life. But in the scientific community there is an opinion that corruption both entails various serious negative consequences for society and has a certain positive impact on it. Therefore, in relation to the issue under consideration, we distinguish two approaches: traditional and revisionist.

Representatives of the traditional approach (K. Friedrich, D. Simson, D. Eitzen, etc.) are characterized by an extremely negative attitude towards corruption. It is viewed as a destructive phenomenon, a "disease" of society. According to Friedrich, corruption is a negative phenomenon, a "pathology of politics." Therefore, it needs to be vigorously rebuffed so that its disease-causing germs do not spread and destroy the political system. According to L. M. Kolodkin, "corruption, like rust on metal, spoils, corrodes, destroys the system of public administration, generates a negative attitude towards public service and employees, a decline in the authority, the prestige of service in public office, deterioration of quality indicators characterizing the personnel corps modern bureaucracy, and therefore undermines the idea of statehood".

The revisionist approach to the issue of influence of corruption on social development is associated mainly with the study of the problems of the third world countries. Representatives of this trend K. Leyles and others oppose a one-sided-negativist attitude towards corruption as a destructive social phenomenon. They argue that corruption can play a positive role in integrating, developing and modernizing Third World societies. For example, according to J. Scott, many forms of corrupt practices condemned by the international community (such as party corruption, sale of public office), which are now widespread in developing countries, were previously characteristic of modern developed societies. Moreover, they played an important role in the formation of their political systems. "When analyzing corruption in young states, first of all, an anti-historical interpretation should be avoided ... Often exaggerated, but quite real shifts that have occurred simultaneously in the standards of behavior that are expected of officials, and in the ways of imposing these standards, should not overshadow the fact, that the practices of the pre-industrial and industrializing West are very similar to those in the pre-industrial and industrializing non-Western world" [25, p. 19]. The point of view of Leff is also worth noting, who argues that corruption increases the social welfare of developing countries, since it allows avoiding excessive regulation and building a system of adequate remuneration for the work of underpaid civil servants.

Thus, based on the positions of the traditional and revisionist approaches, we can conclude that corruption plays both negative and positive role. In some aspects or under certain conditions, it can have a positive impact on society. Therefore, it is appropriate to talk about both negative and positive functions of corruption in the life of society.

First of all, it is necessary to consider the socially destructive functions of corruption. The negative impact of corruption affects all areas of public life. Therefore, for the convenience of describing them, let us single out the economic, political and social consequences of corruption.

The negative economic consequences include the following.

1. There is an increase in the scale of shadow economy, leading to a decrease in tax revenues and a weakening of the state budget. Almost any manifestation of corruption, economic crime, financial and economic abuse is often directly or indirectly associated with the concealment of income and tax evasion. Therefore, due to the wide spread of 
corrupt practices, one can expect an increase in the volume of the shadow economy and a reduction in tax revenues to the state budget. As a result, the state is losing financial levers of economic management, and social problems are aggravated due to non-fulfillment of budgetary obligations.

2. Budget funds are spent ineffectively in the distribution of state and municipal orders, loans, benefits, subsidies. When forming the budget, due to the vested interests of officials, preference will be given to unnecessary purchases and projects, instead of to those best meeting the needs of the state. The number of endless and unnecessary projects will grow, where the costs of such projects will never be offset by the potential profit from their implementation. The cost will grow, the criteria for the quality of the conclusion of the contract will move away, and far from the best goods will purchased. This further aggravates the budgetary problems of the state.

3. Competitive market mechanisms are violated, since the advantage is gained not by the competitive subject of market relations, but by the one who was able to gain an advantage due to corrupt ties with government officials. This entails a decrease in the efficiency of competitive market mechanisms and discrediting the idea of market competition.

4. There is an increase in prices for goods and services as a result of corruption overhead costs of entrepreneurs associated with interaction with government agencies regarding the conduct of commercial activities. Officials often force businessmen to pay bribes, which translate into a kind of additional taxation, which is ultimately passed on to the consumer in the form of inflated prices.

5. Market entities have a lack of faith in the ability of the authorities to establish, control and comply with the rules of market competition, "which deprives the entrepreneur of incentives for effective innovation". And the country's investment climate is also deteriorating, since, provoking an increase in uncertainty, corruption acts as a multiplier of investment risks and a limiter of investment volumes, which slows down economic growth and reduces its competitiveness. The result of all these losses is a decrease in the rate of economic growth and a slowdown in the formation of a normal market economy.

The political consequences of corruption are manifested in the following destructive tendencies.

1. There is a destructive impact on the foundations of the state structure and the foundations of legal regulation of society. Public policy objectives are shifting away from national development towards securing the objectives of the groups in power. In practice, when the functions of the state become the subject of market relations, the state is reborn into an institution of enrichment for the ruling elite, which leads to deformation of the state structures themselves, turning them into formal legal entities operating on the principles of mutual responsibility, while shifting the functions of state institutions to support group or personal interests [29, p. 158]. In such actions of politicians, one can see two essential signs: serving the interests and self-interest, which is paid for $[30, \mathrm{p} .88]$. As a result, the state ceases to fulfill the functions imposed by society.

2. The mechanism of the state administrative apparatus is deformed, there is a deterioration in the quality indicators of its work, the personnel characteristics of the composition of the bureaucracy, its bureaucratization occurs, i.e. the development and adoption of management decisions become less effective.

3. The public's confidence in government officials is decreasing, there is a negative attitude towards public service and employees, a decline in the authority of the authorities, the prestige of service in public positions. The majority of the population is developing a rejection of both the published normative legal acts and the practical actions of the government. On the whole, a negative attitude of citizens towards all the ongoing reforms 
of the government is being formed. "There is a steady decline in the legitimacy of the elite".

4. Political competition is profaned and reduced. Citizens become disenchanted with the values of democracy, as the electoral process turns from an expression of the will of society into a formal action. The political struggle turns into a confrontation between corrupt clans, in which corruption exposures become a reliable weapon in the fight against political opponents. Decomposition of democratic institutions arises. The risk of the collapse of the emerging democracy in the common scenario of the coming of the dictatorship on the wave of the fight against corruption is increasing.

5. The country's prestige in the international arena is falling, and the threat of its economic and political isolation is growing.

6. Due to the spread of interethnic, transnational corruption processes in the field of international relations, the possibility of interference of other countries in the internal politics of the state is created. In the conditions of the impoverishment of the third world countries and countries with economies in transition, the industrially developed countries of the first world are able to overthrow unwanted governments through corruption, establish loyal regimes, and feed opposition to the current authorities.

The social negative consequences of the spread of corruption in society include the following.

1. The diversion of colossal funds from the goals of social development. To derive selfish gain, officials channel state resources into areas of activity where it is difficult to control the cost of products (for example, public works, construction, defense sector, etc.). According to Alice Warhurst, "corruption removes money from important services such as health care systems, education, clean water supply, flood protection". Consequently, the corrupt actions of civil servants change the structure of government spending in such a way that much less funds are allocated to priority areas of social development of society.

2. Consolidation and increase of property inequality and poverty of the majority of the population. Corruption mechanisms, redistributing colossal funds (for example, during privatization), act against the poorest segments of the population. Kaufman notes that "although richer households pay higher bribes than poor households, the pressures of corruption (the percentage of income spent on bribes) are much stronger for the poorest households". Thus, corruption spurs an unfair redistribution of funds in favor of narrow groups at the expense of the most vulnerable strata of the population, increasing the property polarization of society, significantly expanding the scale of social disadvantage.

3. Corruption directly contributes to the criminalization of society because the corruption of law enforcement agencies contributes to the strengthening of organized crime. Organized criminal groups use corrupt government officials to create an environment conducive to impunity for criminal organizations in their operations; neutralization of both individuals and entire institutions; obtaining information of a commercial nature; to create conditions for making super-profitable transactions; obtaining information on measures taken by state bodies to fight and neutralize such actions. As a result, organized crime, merging with corrupt groups of officials and entrepreneurs, provides impunity for their activities and gains opportunities for money laundering. Therefore, according to Alpidovskaya, corruption "accelerates the process of completing the formalization of organized crime into a powerful, ramified system that really claims to be a leader in economics and politics".

4. Social tension is increasing, hitting the economy and threatening political stability in the country.

The consequences of corruption that have a negative impact on the spiritual sphere of society include the following. 
1. Corrupt practices lead to the degradation of moral values of society. The threshold of intolerance of the population to many forms of immoral, antisocial and criminal behavior, which can later be recognized as acceptable and socially approved, is being reduced. Undermining the authority of the state, corruption relieves people joining its ranks from the pangs of conscience - a person who faces injustice from the state, in turn, considers himself entitled to deceive the state.

2. Law is discredited as the main instrument for regulating the life of the state and society. In the public consciousness, a deformation of the legal consciousness of citizens is taking place, legal nihilism is becoming widespread, and an idea of the vulnerability of citizens against crime and in the face of power is being formed. Corruption among top officials constantly reproduces stereotypes of "property immodesty" and imitation of money-grubbing among state and municipal employees, for whom the main criterion of official ethics is not the law, but the boss's lifestyle. As a result, corrupt management personnel are not ready to sacrifice their personal interests for the prosperity of society and the state.

3. The proliferation of corrupt practices in the education system deprives society of a significant part of its intellectual potential, does not allow the most talented young people to get higher education, leads to a distorted career orientation of the intellectual elite of society, focusing it not on creative achievements, but on achieving property success at any cost.

Thus, corruption has a negative impact on all aspects of public life. Therefore, it can rightly be classified as one of the most dangerous and pervasive socially negative phenomena that pose a threat to the national security of the state.

However, as mentioned above, from the point of view of supporters of the revisionist approach, corruption can play a positive role in public life under certain conditions. Let's consider the possible social and constructive functions of corruption.

First, corruption can act as a kind of indicator of the effective - ineffective organization of the work of the state apparatus mechanism. The state as an institution of management of society is designed to ensure external security, maintain internal order in the country, organize the economic system in order to effectively distribute and use public goods. Corruption is becoming widespread due to imperfections of the state management system and the inability to normally perform its intended functions: bureaucratization of power structures, routinization and ritualization of decision-making, excessive interference in the life of citizens, the adoption of legislative norms that inadequately reflect and regulate relations prevailing in society, etc. The level of corruption (in a general sense) in different countries is highly correlated with indicators of the efficiency of the economy functioning, social sphere and political system in these countries, i.e. corruption in a general sense can be viewed as a measure of social inefficiency [37, p. 47]. Therefore, a sharp increase in the number of corrupt acts of civil servants can serve as a signal indicating the need for changes, transformations, reforms both in the civil service system in order to improve the efficiency of its work, and in specific areas of regulating the relationship between society and the government.

Second, it should be noted the positive function of corruption as a shock absorber of institutional shifts. During the period of a cardinal change in the course of social development, old social institutions are being broken down and new ones are being formed. At this point, corruption can be seen as a mechanism to relieve tension between emerging and outdated norms. It helps to establish a balance in their relationship, to move forward on the path of reforming backward sectors and fragments of public life, to strengthen new rational and civilized forms of social and state structure.

Thirdly, corruption can be a kind of "lubricant" for a cumbersome, clumsy, stalled mechanism for making administrative decisions by the state apparatus. In this case, 
corruption, as an alternative to legal forms of behavior, can act as a mechanism to soften strict formal rules, which allows economic agents to weaken the negative impact of ineffective institutions". Under the conditions of the total domination of the administrative principle in the management of society, bureaucratic tricks, "delays" and "troubles" place a heavy burden on the real economy, take away a lot of effort and energy from entrepreneurs, and significantly narrow the scope of opportunities for realizing available resources. Here, a corrupt act can help citizens who turn to the state to solve their problems in the following way. Thanks to a bribe, a dialogue between living people and a faceless state is being established, and mediated positions are given the forms of stimulated relations. As a result, the relationship with the required official takes on a personal character, and citizens have an opportunity to claim solutions to their problems in an exclusive manner. As a result, citizens can achieve the removal of a number of excessive bureaucratic prohibitions, unreasonable nagging on the part of regulatory bodies, accelerating the adoption of the necessary decision, reducing the uncertainty of the price of goods and services distributed by the state.

Finally, it is necessary to note an interesting point of view, according to which corruption in the hands of citizens can play a neutralizing role, a way of their adaptation and survival in relation to the inadequate course of reforms and transformations carried out by the political elite. Corruption allows people to live in conditions where the state is trying in various ways to drive them into a framework determined from the most good, but abstract (in the Hegelian understanding of abstraction) proposals and intentions.

\section{Conclusion}

The conducted research allows us to formulate the following conclusions:

1. Under the conditions of the emergence of certain social situations, corruption can play a special role: at certain historical moments in conditions of ineffective functioning of institutions, corruption creates the illusion of possibility of avoiding the complete disintegration of social organism. The factors that allow corruption to appear in a special role are the weakness of the state, the underdevelopment or powerful transformation of social norms, the insufficient development of the political structure, the absence of civil society, the existence of significant bureaucratic barriers, and deficiencies in legislation that should regulate the decision of political, economic, social, organizational and administrative problems, as well as the lack of clear regulation of activities of officials regarding the procedure for exercising their powers. In such conditions, corrupt relations replace formal ones. Let us emphasize that under the conditions of transition from one type of social structure to another, when the types of political regimes change in society, the process of deformalization of rules often occurs. Its result is the transformation of most social institutions, during which formal rules are sufficiently replaced by informal ones and built into informal relations. Corrupt relations are completing, or rather, building official relations around themselves. The adaptive role of corrupt practices lies in the possibility of accelerating certain processes. Then corruption turns into a powerful lever for development and transformation of society. In this sense, corruption, not being a necessary social phenomenon, under certain conditions prevailing in society, becomes inevitable. At the same time, the authors of this work do not agree with the attempts to apologize corruption, manifested in the reasoning characteristic of the supporters of the revisionist approach to the study of corruption. This view allows us to talk about the possibility of overcoming a number of problems with the help of corruption tools in the near term. At the same time, solving certain (albeit significant) problems today, corruption does not provide an opportunity to improve the situation tomorrow. Moreover, if all members of society predominantly use corrupt mechanisms, follow corrupt patterns of behavior in certain 
situations, this will most likely lead to a weakening of the public administration system, a significant decrease in the level of economic development, strong social differentiation of the population, etc.

2. The positive effect of the existence of corrupt practices in society is unequivocally incomparable with the negative consequences of this phenomenon.

3. When assessing the nature of the impact of corruption on public welfare, it is necessary to take into account that the ratio of the constructive and destructive consequences of this phenomenon in different social systems and at different stages of their historical development varies. In some states, where the prevalence of various forms of abuse of their powers among officials is low, corruption does not undermine the foundations of statehood, does not interfere with the normal functioning and development of society, and, therefore, does not pose a serious danger. In other states, where corruption spreads to all spheres of life, turns into a norm and tradition, it reduces the overall efficiency of public administration and becomes an acute social problem that can lead to the destruction of social system.

\section{References}

1. A. Bystrova, M.V. Silvestros, Journal of Sociology and Social Anthropology 111(1), 83-100 (2000)

2. N. Pravnikova, Social and legal problems of economic development: Interfaculty collection of scientific papers (University book, M., 2012)

3. A.S. Minzov, Bulletin of the Russian University. G.V. Plekhanov 2, 5-15 (2012)

4. Yu.V. Latov, Investigator 2, 38-41 (2014)

5. G.A. Satarov, Social sciences and modernity 2, 60-69 ((2004)

6. Lawler J. Edward, L. Hipp, Advances in Group Processing 27, 269-296 (2019)

7. A.A. Kontarev, Jurist-Pravoved 4, 10-13 (2008)

8. Naiwei Chen, Corporate Governance: An International Review 19, 3-24 (2011)

9. D. Lange, Academy of Management Review 33(3), 710-729 (2008)

10. N. Leff, American Behavioral Scientist 8(3), 8-14 (1964)

11. A. Tsurikov, V. Tsurikov, Economic Issues 1, 45-54 (2007)

12. S.S. Sulakshin, Free thought 4, 78-91 (2005)

13. A. Warhurst, Global Corruption Report: Climate Change (Transparency International, 2011)

14. V.P. Korzh, State and Law 8, 55-58 (2002)

15. M.L. Alpidovskaya, Management in Russia and abroad 1, 136-140 (2008)

16. L. Grigoriev, M. Ovchinnikov, Economic Issues 2, 44-60 (2008)

17. V.F. Lapshin, S.A. Korneev, E3S Web of Conferences 135, 04063 (2019) DOI: 10.1051 / e3sconf / 201913504063

18. A.A. Brovkina, V.E. Vezlomtsev, S.S. Zakharova, O.A. Shuranova, Yu.V. Truntsevsky, E3S Web of Conferences 135, 04066 (2019) DOI: 10.1051 / e3sconf / 201913504066 